\title{
Chapter 4 \\ With a View Toward Initiating Regional \\ Entrepreneurship-Based on Data \\ Analysis and Survey Research \\ of Hometown Tax Donation Gift \\ Providers
}

Keywords Regional entrepreneurship $\cdot$ New product development $\cdot$ New business development $\cdot$ Regional development $\cdot$ Product innovation

\subsection{The Need to Grasp the Current State of Hometown Tax Donation Gift Providers}

The previous chapter examined several cases where local SMEs (i.e., gift providers) enhanced their business motivation or skills through providing gifts for Hometown Tax Donation, a system unlike conventional SME support policies. If similar cases can be found in other regions nationwide, this may offer political implications for creating an ecosystem that initiates much-needed regional entrepreneurship in Japan. To gain insight into elements necessary in fostering local businesses, this chapter introduces results of a survey that asked gift providers about the seeds of regional entrepreneurship deriving from Hometown Tax Donation.

Among the 1741 municipalities eligible to receiving Hometown Tax Donations, 962 have populations of fewer than 30,000, among which 519 have populations of fewer than 10,000 (as of January 1, 2020, according to the MIC; population by municipality based on Basic Resident Registers). While companies located in large cities would have advantage in normal business since they are in proximity to a large metropolitan customer base, rural companies have less disadvantage in Hometown Tax Donation since urban residents commonly donate to rural areas. In fact, among the 20 municipalities that received the most Hometown Tax Donations, 13 in fiscal year 2018 and 9 in fiscal year 2019 had populations of fewer than 30,000, implying that small municipalities are not necessarily disadvantaged.

This chapter is based on Hoda and Kubo (2019a, b), with some edits, reconstructions and additions. 
Meanwhile, some municipalities have raised concern that the gap will widen between regions with and without attractive local specialties. Even if a municipality is small in size, having a nationally renowned business in the region may place the municipality in an advantageous position. If gifts are being provided by relatively large businesses with surplus capital and capacity, gifts cannot be expected to have much impact on driving innovation or fostering local businesses. On the contrary, if gifts are prompting SMEs to develop new businesses, as seen in the previous chapter, such impacts may be expected.

Thus, in order to understand what kind of local businesses are being influenced by the gift market, this chapter depicts an overview of gift providers by unveiling their attributes and the impact gift revenue has on them.

\subsection{Method of Survey Research on Gift Providers' Attributes and Improvement in Their Management Capabilities}

Of the top 20 municipalities that received the largest donations in fiscal year 2016, we excluded Kumamoto City, which received large donations for earthquake disaster relief efforts, and asked the remaining 19 municipalities for their cooperation, among which 15 consented (hereinafter referred to as "top regions"). Additionally, we randomly selected 10 other municipalities (hereinafter referred to as "randomly selected regions") and conducted the same survey for purpose of comparison. We sent a set of surveys to each municipality by postal mail (on December 6, 2017), and asked the municipalities to forward the surveys to all gift providers in their region. We requested that each business directly send their responses to us via postal mail by the end of January 2018. Surveys were sent out to a total of 1073 businesses (by 25 municipalities), and we received responses from a total of 310 businesses, consisting of 163 in the top regions and 147 in the randomly selected regions (response rate of $28.9 \%$ ). Questions included those on corporate profile and attributes such as revenues and number of employees, their current state of gift provision, changes in business operation or improvement in management capability indices driven by Hometown Tax Donation, and alliances with municipalities. Results were analyzed using simple tabulation, cross tabulation, and t-test. We then compared the impact and changes stemming from Hometown Tax Donation between the top regions and randomly selected regions.

It should be noted that to accurately compare the top regions with other regions, it would be ideal to extract municipalities with attributes similar to each top region as matching samples, and then to group and analyze them as randomly selected regions. However, since it is difficult to elicit cooperation for this kind of survey, we regarded the group of municipalities that cooperated with our survey but were not among the top regions as randomly selected regions. As such, the comparison between the top and randomly selected regions are for reference only. Nonetheless, since donations 
procured by the top 20 regions accounted for one fourth of total donations, the top regions may be unique, and we therefore believe it is important to verify and compare the situation of other regions relative to the top regions, albeit not through proper sample matching.

\subsection{Attributes of Gift Providers}

\subsubsection{Size of Gift Providers}

We will first look at the business size of the gift providers. Figure 4.1 indicates that the majority of Hometown Tax Donation gift providers are typical rural small businesses, with median annual revenues of 100 million yen in top regions and 58 million yen in randomly selected regions, about six to eight employees, and online sales ratio of less than $10 \%$. The distribution by revenue (Fig. 4.2) shows that businesses with annual revenues of 30 million yen or less accounted for nearly $30 \%$ in the top regions and nearly $40 \%$ in the randomly selected regions. Meanwhile, businesses with annual revenues exceeding 500 million yen accounted for some $20 \%$ in both regions. Since no significant difference was detected in business size between the top and randomly selected regions, with similar proportions of large businesses in both regions, business size does not seem to be a determinant for becoming a top region.

Regarding the distribution by number of employees, small businesses with five or fewer employees accounted for some $40 \%$ in both the top and randomly selected regions (Fig. 4.3). Most are presumably family-run businesses. In conjunction with aforementioned total revenue levels, it was verified that many rural micro businesses are participating in the Hometown Tax Donation gift market. Such small businesses

\begin{tabular}{|c|c|c|c|c|c|c|}
\hline & \multicolumn{2}{|c|}{ Average } & \multicolumn{2}{|c|}{ Median } & \multicolumn{2}{|c|}{ SD } \\
\hline & Top regions & $\begin{array}{c}\text { Randomly } \\
\text { selected } \\
\text { regions }\end{array}$ & Top regions & $\begin{array}{c}\text { Randomly } \\
\text { selected } \\
\text { regions }\end{array}$ & Top regions & $\begin{array}{c}\text { Randomly } \\
\text { selected } \\
\text { regions }\end{array}$ \\
\hline Revenues ( $¥ \mathrm{mn}$ ) & 503.3 & 832.8 & 100.0 & 58.0 & 1135.8 & $3,146.8$ \\
\hline Extra-regional sales ratio (\%) & $44.5 \%$ & $39.8 \%$ & $50.0 \%$ & $30.0 \%$ & $34.5 \%$ & $33.9 \%$ \\
\hline Online sales ratio $(\%)$ & $14.8 \%$ & $12.0 \%$ & $9.0 \%$ & $5.0 \%$ * & $22.3 \%$ & $21.3 \%$ \\
\hline B2B sales ratio (\%) & $44.4 \%$ & $49.1 \%$ & $40.0 \%$ & $50.0 \%$ & $36.3 \%$ & $38.8 \%$ \\
\hline No. of employees (ppl) & 18.5 & 27.3 * & 8.0 & 6.5 & 25.2 & 64.6 \\
\hline Female employment ratio (\%) & $50.65 \%$ & $46.4 \%$ & $50.0 \%$ & $50.0 \%$ & $27.0 \%$ & $31.2 \%$ \\
\hline
\end{tabular}

Fig. 4.1 Basic attributes of gift providers. Note Categories marked with "*”" are those with a significance level of $5 \%$ between the top and randomly selected regions. The number of respondents was 163 for the top regions and 147 for the randomly selected regions. "Extra-regional sales ratio," "online sales ratio," and "B2B sales ratio" are ratios to total revenues of revenue from outside the prefecture, revenue from online sales, and revenue from wholesale 
4 With a View Toward Initiating Regional Entrepreneurship ...

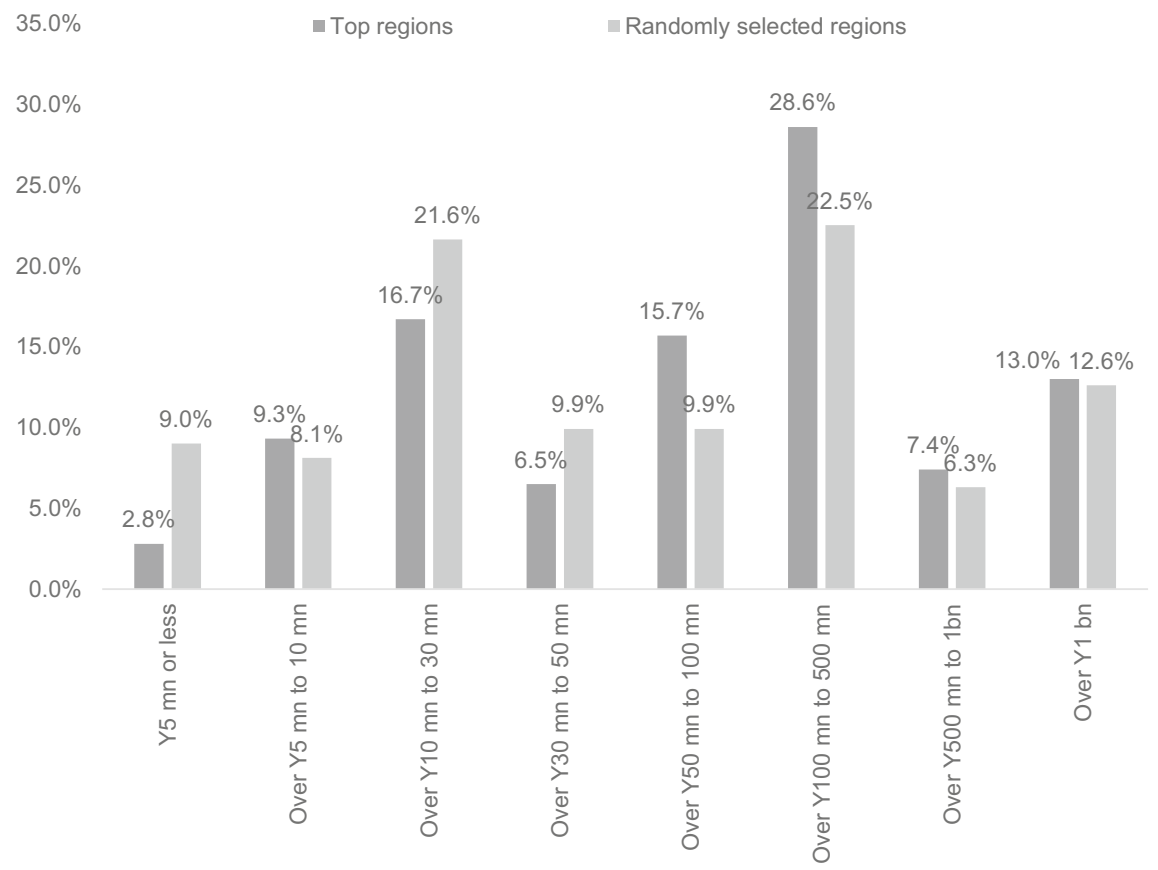

Fig. 4.2 Distribution of gift providers by revenue

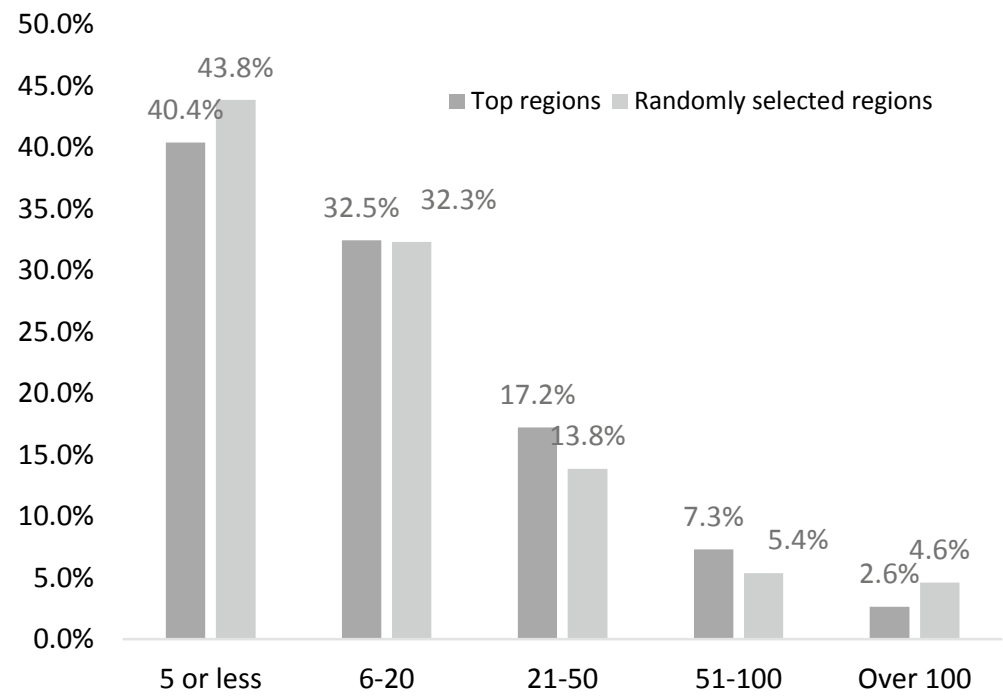

Fig. 4.3 No. of employees of gift providers 
a Top regions Randomly selected regions

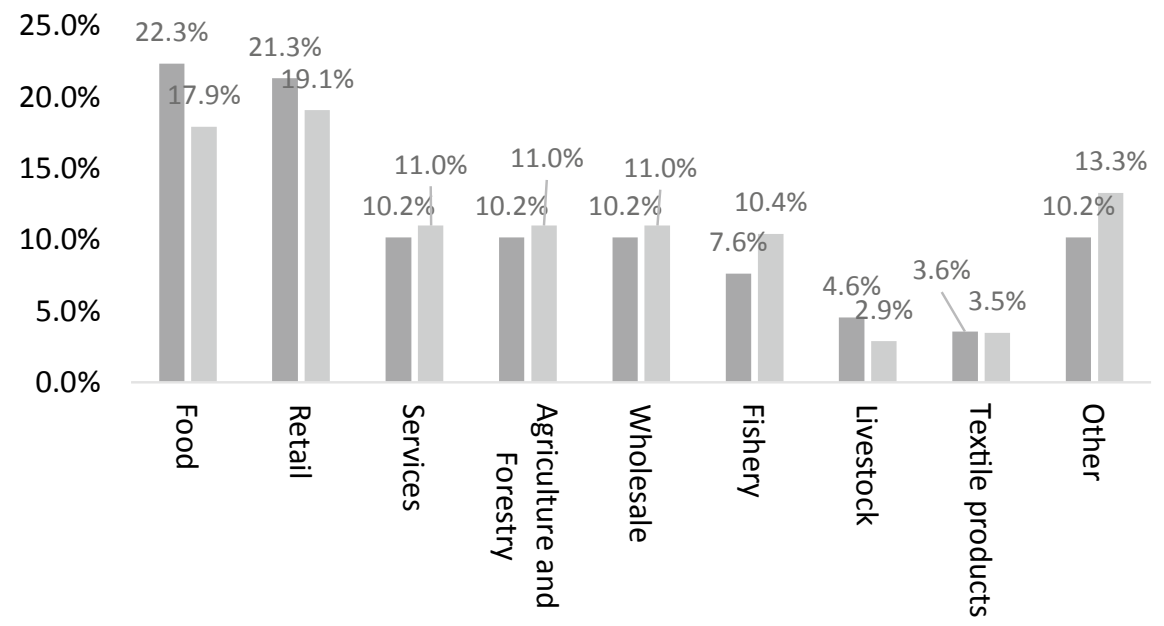

Fig. 4.4 Industry of Gift Providers. Note Since the question is multiple choice, some businesses apply to more than one industry

are presumably not equipped to start handling gifts, and to compete in the gift market, they will need to collaborate with other local businesses in order processing and backoffice operations, with the backup of municipalities or local trading companies. In reverse, businesses within regions that offer such intra-regional support may gain a competitive edge in the gift market. It is worth noting that businesses with over 50 employees accounted for merely $10 \%$. Since the MIC suggests that gifts should be local specialties, one can assume that relatively large companies that produce and sell national brand products are excluded from the gift market.

As for industries of gift providers, although food and retail account for some $40 \%$, the inclination is relatively small with no dependency on specific industries (Fig. 4.4). Gifts therefore do not seem to exclusively support specific industries.

\subsubsection{Breakdown of Gift Providers' Revenues}

Ratio of sales from outside the prefecture to total revenues (i.e., extra-regional sales ratio) was $50.0 \%$ in top regions and $30.0 \%$ in randomly selected regions; however, the breakdown shows that businesses in both the top and randomly selected regions could be divided into a group with high extra-regional sales ratios and a group with low ratios (Fig. 4.5). One can argue that the gift market reinforced extra-regional sales for businesses that were originally strong in this area, while offering businesses that originally had low extra-regional sales ratios an opportunity to enter extra-regional markets. 


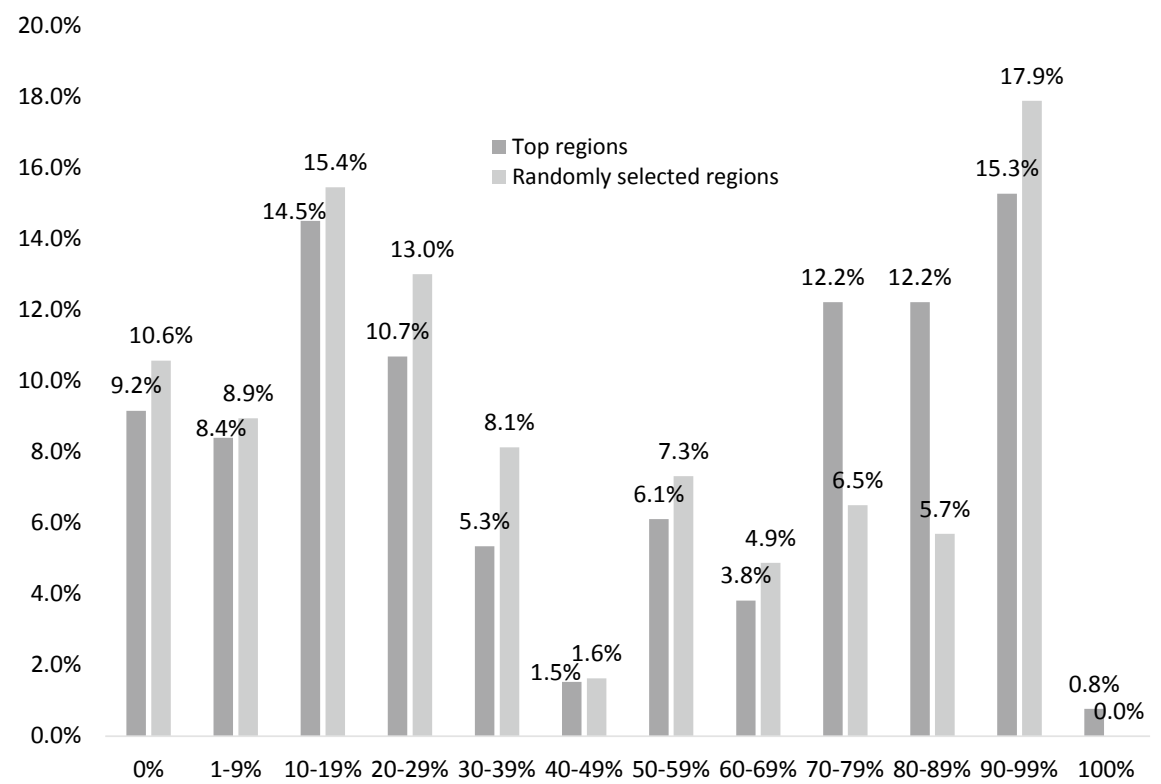

Fig. 4.5 Extra-regional sales ratio of gift providers

Ratio of online sales to total revenues was $9.0 \%$ in the top regions and $5.0 \%$ in the randomly selected regions (Fig. 4.1; median), presenting a significant difference. One interpretation is that regions where there were originally many businesses adept at online sales became top regions, while another interpretation is that businesses gained online sales know-how prompted by Hometown Tax Donation and increased their online sales ratio. The distribution shows that some $80 \%$ of the businesses in both regions have an online sales ratio of less than $20 \%$, implying that many businesses inexperienced in online sales are entering into the gift market (Fig. 4.6). In other words, the gift market may be offering rural SMEs opportunities to experience and try out online sales.

Next, the distribution by ratio of B2B sales to total revenues (i.e., B2B sales ratio) can be categorized into a group of businesses centered on $\mathrm{B} 2 \mathrm{~B}$, and a group of businesses centered on B2C (Fig. 4.7). Businesses with a B2B sales ratio of over $80 \%$ accounted for over $30 \%$ in top regions and nearly $40 \%$ in randomly selected regions - these businesses may be leveraging the gift market to enter into the $\mathrm{B} 2 \mathrm{C}$ realm. Rural businesses who have difficulty directly accessing urban customers often settle for low-margin wholesales; however, such businesses may be attempting a breakthrough by using the gift market, as seen in the previous chapter with the apparel manufacturer based in Kitakami City, Iwate Prefecture, which used the gift market as a foothold to enter into the B2C market from wholesales. 


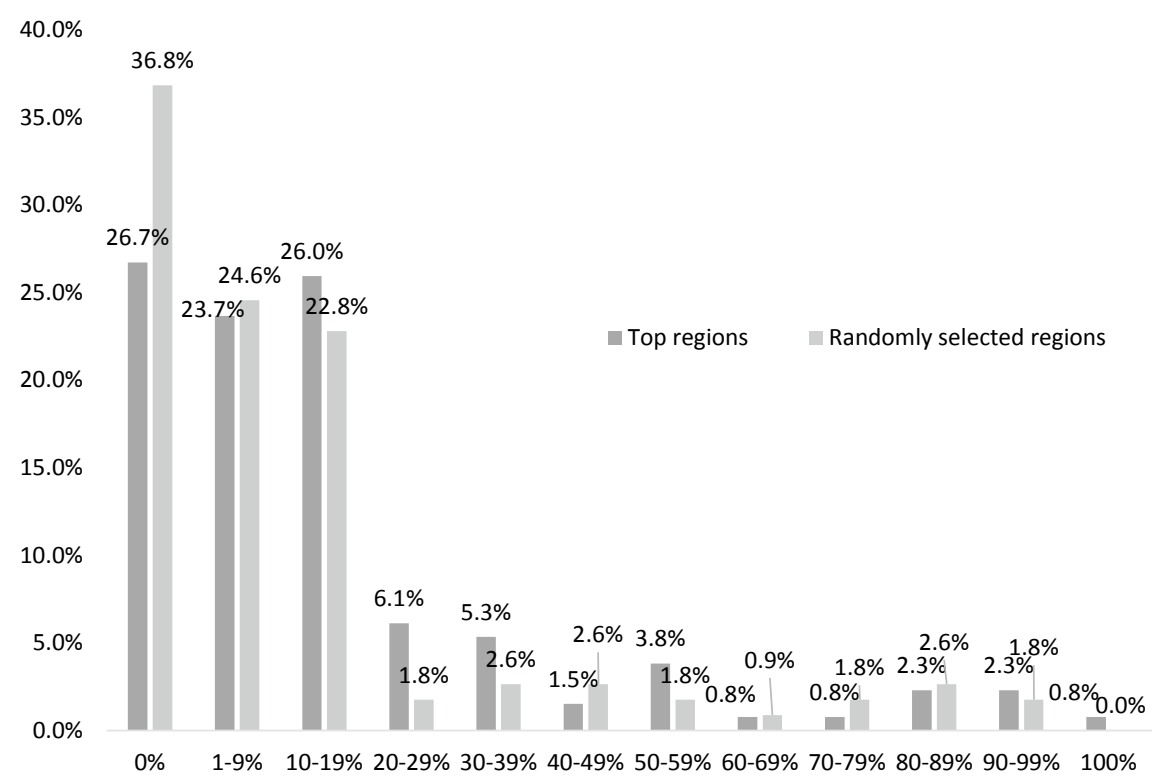

Fig. 4.6 Online sales ratio of gift providers

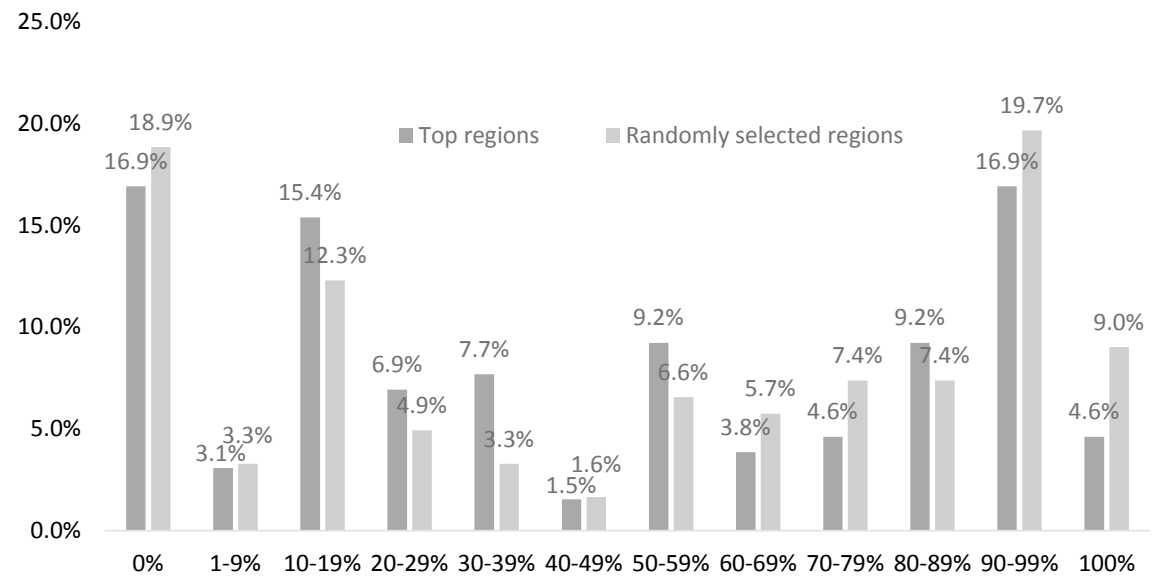

Fig. 4.7 B2B sales ratio of gift providers

\subsubsection{Gift Revenue by Amount and by Ratio to Total Revenues}

Gift revenue per business was 1.9 million yen in the top regions and 1.2 million yen in the randomly selected regions (Fig. 4.8; median of 2017). The distribution shows that businesses with gift revenue of less than 5 million yen accounted for $64.0 \%$ 


\begin{tabular}{|c|c|c|c|c|c|c|c|c|}
\hline \multirow[b]{3}{*}{ (Ymn) } & \multicolumn{4}{|c|}{2016} & \multicolumn{4}{|c|}{2017} \\
\hline & \multicolumn{2}{|c|}{ Top regions } & \multicolumn{2}{|c|}{$\begin{array}{l}\text { Randomly } \\
\text { selected regions }\end{array}$} & \multicolumn{2}{|c|}{ Top regions } & \multicolumn{2}{|c|}{$\begin{array}{c}\text { Randomly } \\
\text { selected regions }\end{array}$} \\
\hline & No. & $\%$ & No. & $\%$ & No. & $\%$ & No. & $\%$ \\
\hline $0-1$ & 33 & $29.2 \%$ & 39 & $39.8 \%$ & 45 & $33.1 \%$ & 59 & $47.6 \%$ \\
\hline $1-5$ & 32 & $28.3 \%$ & 32 & $32.7 \%$ & 42 & $30.9 \%$ & 36 & $29.0 \%$ \\
\hline $5-10$ & 7 & $6.2 \%$ & 5 & $5.1 \%$ & 11 & $8.1 \%$ & 6 & $4.8 \%$ \\
\hline $10-30$ & 19 & $16.8 \%$ & 15 & $15.3 \%$ & 15 & $11.0 \%$ & 13 & $10.5 \%$ \\
\hline $30-50$ & 7 & $6.2 \%$ & 2 & $2.0 \%$ & 8 & $5.9 \%$ & 4 & $3.2 \%$ \\
\hline $50-100$ & 4 & $3.5 \%$ & 3 & $3.1 \%$ & 6 & $4.4 \%$ & 4 & $3.2 \%$ \\
\hline $100-$ & 11 & $9.7 \%$ & 2 & $2.0 \%$ & 9 & $6.6 \%$ & 2 & $1.6 \%$ \\
\hline Total & 113 & $100.0 \%$ & 98 & $100.0 \%$ & 136 & $100.0 \%$ & 124 & $100.0 \%$ \\
\hline Not answered & 50 & & 49 & & 27 & & 23 & \\
\hline Average revenue & & Y43.6mn & & Y10.7mn & & Y26.1mn & & $\mathrm{Y} 12.8 \mathrm{mn}$ \\
\hline Median revenue & & Y3.6mn & & Y1.6mn & & $\mathrm{Y} 1.9 \mathrm{mn}$ & & $\mathrm{Y} 1.2 \mathrm{mn}$ \\
\hline SD of revenue & & $137.0 \mathrm{mn}$ & & Y29.8mn & & Y79.8mn & & Y65.8mn \\
\hline
\end{tabular}

Fig. 4.8 Gift revenue (per business/annual)

in the top regions and $76.6 \%$ in the randomly selected regions, indicating that gift revenue per business is not so large overall. Comparing 2016 with 2017, the ratio is lower as a whole in 2017. This is because more businesses joined the gift market in each region, implying wider engagement within regions.

Meanwhile, businesses whose gift revenue was 100 million yen or more accounted for $6.6 \%$ in the top regions and $1.6 \%$ in the randomly selected regions (in 2017). The fact that certain businesses are earning large revenue may be interpreted in two ways. On the one hand, one might argue that the larger the size of a business, the more apt they are at handling gifts; hence the more they would benefit from the system, spreading the disparity between local businesses further. This would cause a dilemma where the system intended to foster local SMEs is, in reality, benefiting relatively larger businesses. On the other hand, the presence of such established local businesses may lead to better recognition of the region, and in turn, benefit smaller businesses. High regional profile and strong regional PR capabilities are important particularly since Hometown Tax Donation is a system where individuals donate to municipalities. The presence of a renowned business in the region is essential in procuring donations, and wider recognition of the region should benefit other businesses as well. Therefore, it would be naive to simply criticize the fact that certain businesses are making large profits through gifts.

The ratio of gift revenue to total revenues per gift provider (Fig. 4.9) was $10.0 \%$ in top regions and 8.0\% in randomly selected regions (median for 2017), suggesting that, as a whole, dependency on gifts is not so high. Nonetheless, businesses whose gift revenue exceeded $50 \%$ of total revenues was $14.0 \%$ in the top regions and $10.4 \%$ in the randomly selected regions (in 2017)—such businesses require attention since 


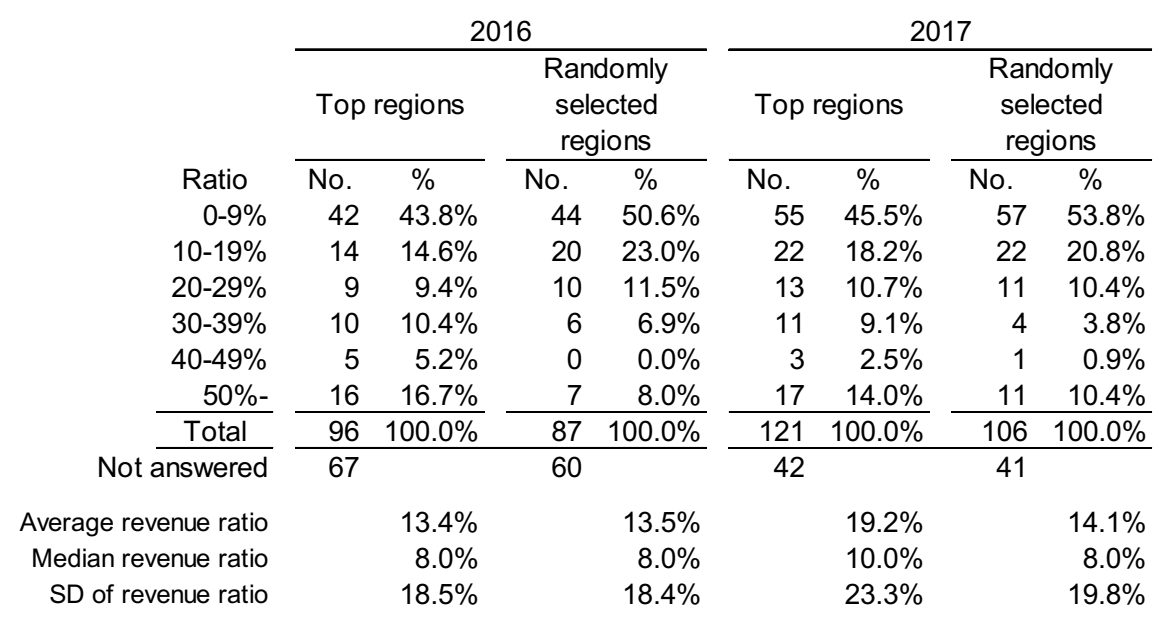

Fig. 4.9 Ratio of gift revenue to total revenues

they are excessively dependent on Hometown Tax Donation and their financial results are susceptible to the system.

The two tables above imply that it is essential to establish a flexible policy that offers more support to businesses with small gift revenue or with low ratio of gift revenue to total revenues until they gain a competitive edge, while offering less support to those with opposite traits. The policy should be designed to give guidance to those that are not fully leveraging the system, while redirecting businesses that are inclined to rely on the system.

\subsubsection{Summary of Attributes of Gift Providers}

This section unveiled the attributes of local businesses participating in the Hometown Tax Donation gift market, and the impact of gift revenue on businesses. Analysis results showed that over $40 \%$ of the gift providers are small businesses with five or fewer employees, and that some $80 \%$ are businesses with an online sales ratio of less than $20 \%$. The gift market mostly consists of rural SMEs, and may be offering them an opportunity to take their first step and experiment with online sales. This is important especially for rural areas with contracting trading areas. The gift market also seems to be driving some $\mathrm{B} 2 \mathrm{~B}$ companies to enter into the $\mathrm{B} 2 \mathrm{C}$ realm.

Thus, the gift market is offering wide-ranging opportunities to local SMEs, and by leveraging local SMEs, even regions with weak local industries or lacking specialties should be able to procure Hometown Tax Donations. On another note, although dependency is not high as a whole, some businesses seem to rely heavily on gift revenue, and it is therefore necessary to establish a system that avoids excessive dependency on the gift market, with an exit strategy in sight. Moving forward, the 
challenge will be for local businesses to enhance their skills in the gift market and pave the way for competently striving in other markets as well.

\subsection{Survey Results Regarding Enhancing Management Capabilities of Gift Providers}

\subsubsection{Changes in Gift Providers}

\subsubsection{Changes in Business Motivation and Management Capability Indices}

Figure 4.10 shows results to questions on whether providing gifts of Hometown Tax Donation enhanced business motivation or management capability indices on a scale of 5 ranging from "Does not apply (1 point)" to "Applies (5 points)" (targeting the top regions). Results show that significant positive effects were felt in product quality management, rise in customer satisfaction, intra-regional and extra-regional branding capability and awareness, packaging method, motivation for new product development, product design capabilities, and transformation of management's mindset.

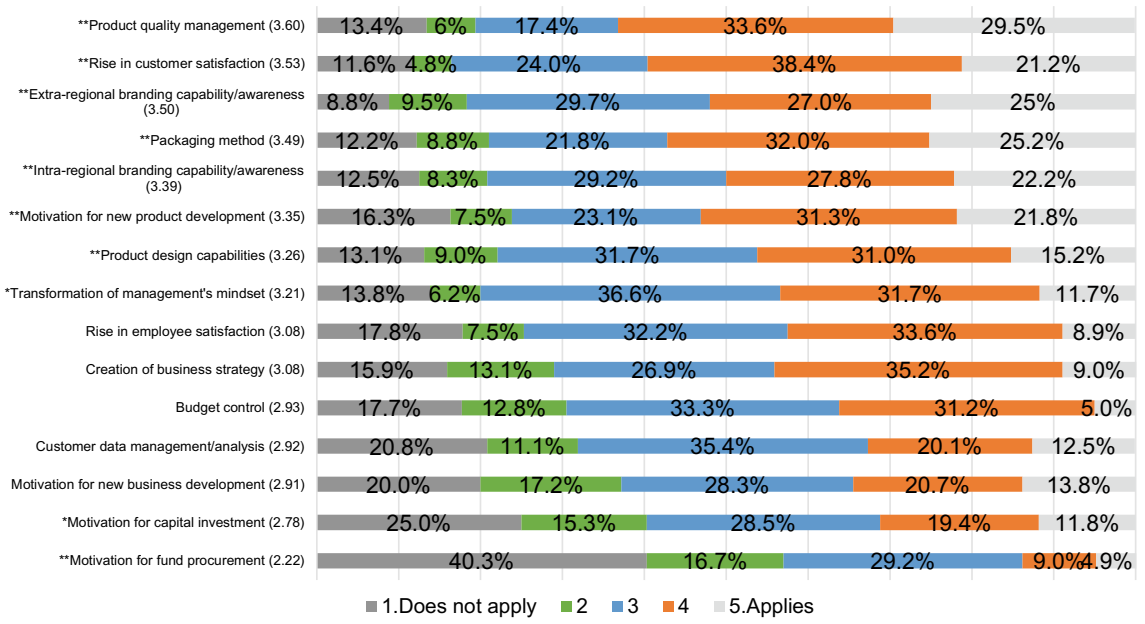

Fig. 4.10 Changes in management capability indices through the gift market (in the top regions). Note Rating from 1 to 5 in 1-point increments. Respondents consist of 163 businesses in the top regions. Values are the average value of responses excluding "Not answered." A test was applied to the difference from 3, which is the median score of the responses. Categories marked with "***" and "*" are those with significance levels of 1 and 5\% 
Change in extra-regional branding capability and awareness was the result of businesses reaching out to previously inaccessible customer bases through gift web portals.

Businesses can also benefit from extensive advertising and promotion that would not be possible otherwise, since municipalities take the initiative in this field as part of promoting the region. In effect, local businesses are making a concerted effort to conduct advertising and promotion by raising their buying power toward general media and advertising media. It is interesting that positive effects were also seen in intra-regional brand capability and awareness. According to our interview with businesses, this was the result of locals reappraising their region after learning of the rise in extra-regional brand capability and awareness.

Product quality management, rise in customer satisfaction, packaging method, and product design capabilities are all improvements in skills. Web portals introducing gifts contain user reviews, similar to typical online shopping sites. Such improvements in management capabilities are likely the result of local businessesoriginally mostly targeting local customers or in the wholesale trade and not having direct contact with customers - striving to deal with rigorous assessment mainly by urban consumers.

Higher motivation to develop new products and transformation of management's mindset signify that provision of gifts is leading to regional entrepreneurship by functioning as a dojo (i.e., training platform, originally for martial arts) for local businesses. However, it should be noted that there was a significant negative effect in motivation for fund procurement and capital investment. Hence, although gifts are initiating regional entrepreneurship, they are not boosting motivation for capital investment or financing. This situation implies that regional entrepreneurship triggered by provision of gifts is restricted to what can be done within the range of existing facilities and equipment or financial capacities.

\subsubsection{Initiatives Toward Developing New Products or Businesses}

Next, we examine changes in businesses and implementation of product-related initiatives. Figure 4.11 shows that more than one out of three businesses in both the top and randomly selected regions developed new products or businesses. This finding is significant considering the fact that most respondents were rural SMEs.

Such cases are seeds of regional entrepreneurship stemming from provision of gifts, and should have a profound impact on regions encountering economic slowdown. In our interviews with local businesses, some mentioned that they are not motivated to develop new products for the local market, and even if they did, it could push down revenues of existing products; thus, they face a dilemma when engaging in intra-regional innovation.

Interviewees also mentioned that even if they did possess the skills to produce high-quality products, there is no demand for such products locally, so products are not commoditized. However, the momentum to develop new products has risen with the emergence of the extra-regional gift market mainly consisting of urban 


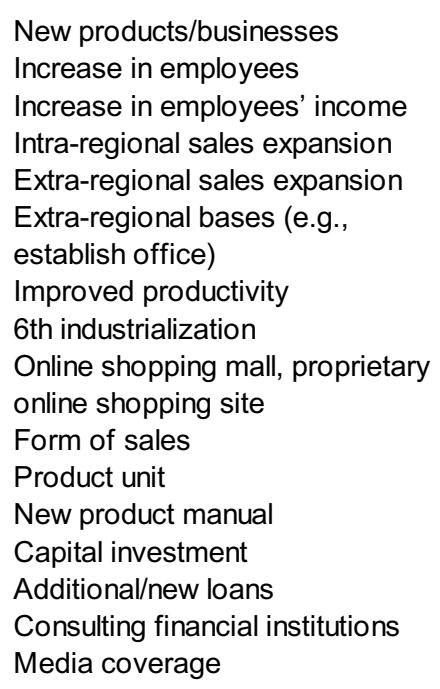

\begin{tabular}{rr}
\multicolumn{2}{c}{ Changes experienced } \\
\hline Top regions & $\begin{array}{c}\text { Randomly } \\
\text { selected } \\
\text { regions }\end{array}$ \\
& $35.3 \%$ \\
$28.1 \%$ & $13.8 \%$ \\
$25.5 \%$ & $19.5 \%$ \\
$25.3 \%$ & $19.9 \%$ \\
$22.3 \%$ & $16.7 \%$ \\
$2.7 \%$ & $4.0 \%$ \\
$29.5 \%$ & $24.8 \%$ \\
$32.5 \%$ & $23.9 \%$ \\
$27.8 \%$ & $16.8 \%$ * \\
$8.3 \%$ & $6.7 \%$ \\
$14.2 \%$ & $12.6 \%$ \\
$32.6 \%$ & $27.9 \%$ \\
$20.1 \%$ & $12.1 \%$ * \\
$11.8 \%$ & $3.0 \%$ ** \\
$5.6 \%$ & $4.5 \%$ \\
$36.2 \%$ & $35.0 \%$
\end{tabular}

Fig. 4.11 Changes caused by providing gifts. Note Values are ratios to the total number of responses excluding "Not answered." The number of respondents was 163 for the top regions and 147 for the randomly selected regions. Categories marked with "**" and "**" are those with significance levels of 5 and $1 \%$ between the top and randomly selected regions

consumers. As introduced in the previous chapter, catalana, a gift of Osaki Town in Kagoshima Prefecture, was developed by accurately predicting urban demand for high-class products, and became popular, whereby demand for local sales also emerged, leading to sales in michi no eki and local convenience stores. In fact, many businesses have taken measures including to extend expiration date to withstand long-distance deliveries or develop ambient food products.

\subsubsection{Effects on Expanding Sales Channels}

Intra-regional sales rose in $25.3 \%$ of the businesses in the top regions and $19.9 \%$ in the randomly selected regions. These are cases where local specialties became popular in the gift market and earned high reputation from non-locals, and consequently gained local popularity as well. There are also movements to strategically market products that gained popularity in the gift market as local specialties targeting nonlocal travelers and visitors.

Similarly, $22.3 \%$ of the businesses in the top regions and $16.7 \%$ in the randomly selected regions have experienced an increase in extra-regional sales. These are cases where products gained recognition through Hometown Tax Donation and 


\begin{tabular}{|c|c|c|c|c|}
\hline \multirow[b]{2}{*}{ Sales channel } & \multicolumn{2}{|c|}{$\begin{array}{c}\text { Intra-regional } \\
\text { sales expansion }\end{array}$} & \multicolumn{2}{|c|}{$\begin{array}{c}\text { Extra-regional } \\
\text { sales expansion }\end{array}$} \\
\hline & Top regions & $\begin{array}{c}\text { Randomly } \\
\text { selected regions }\end{array}$ & Top regions & $\begin{array}{c}\text { Randomly } \\
\text { selected regions }\end{array}$ \\
\hline Michi no eki & 11 & 11 & 4 & 3 \\
\hline Wholesale & 11 & 10 & 9 & 3 \\
\hline Supermarket & 4 & 5 & 3 & 3 \\
\hline Restaurant & 5 & 1 & 7 & 1 \\
\hline Online sales & 2 & 0 & 5 & 3 \\
\hline CVS & 1 & 2 & 1 & 1 \\
\hline Other & 18 & 14 & 9 & 9 \\
\hline Total & 52 & 43 & 38 & 23 \\
\hline No. of responden & 39 & 27 & 34 & 21 \\
\hline
\end{tabular}

Fig. 4.12 New intra-regional and extra-regional sales channels

prompted businesses to enter into online sales or other new sales channels. While excavating extra-regional sales channels is especially challenging for rural SMEs, Hometown Tax Donation helps raise recognition of local products and thereby serves as a supportive policy to a certain extent. Intra-regional sales expansion represses consumption outflows and promotes intra-regional circulation of money, while extraregional sales expansion contributes to a rise in regional GDP through increased "foreign currency."

To businesses that replied that they experienced sales expansion, we also asked "to what extent (approximately) was total revenue raised." According to their responses, total revenues were raised by some $10 \%$ for intra-regional sales expansion and some $17 \%$ for extra-regional sales expansion. Sales expanded mainly in shipments to local michi no eki and wholesalers (Fig. 4.12).

\subsubsection{Increase in Employment, Income and Productivity}

Returning to Fig. 4.11, employment increased in nearly $30 \%$ of the businesses in the top regions and nearly $15 \%$ in the randomly selected regions. Also, employees' income rose in $25.5 \%$ of the businesses in the top regions and $19.5 \%$ in the randomly selected regions. The increase rate of employees' income was an average of $9.8 \%$. An increase in employment and income in rural areas should boost regional consumption, which in turn may raise local GDP. Regarding productivity, $29.5 \%$ of the businesses in the top regions and $24.8 \%$ in the randomly selected regions experienced an improvement. According to our interviews, some businesses wanted to hire more personnel to expand production in response to rising gift revenue; however, they were unable to find new local personnel and had to raise productivity while maintaining capacity. Productivity was raised by an average of $15.3 \%$. 


\subsubsection{Changes in Business Style and Sixth Industrialization}

For Hometown Tax Donation to initiate regional entrepreneurship, the system should ideally serve as a dojo for nurturing local businesses so that they would not continue relying on the system. Below, we summarize the results of several questions asked from this perspective. First, $27.8 \%$ of the businesses in the top regions and $16.8 \%$ in the randomly selected regions opened a shop on online shopping malls or launched their own online sales site triggered by Hometown Tax Donation. For businesses in rural areas that face depopulation, market expansion through online sales is important; yet many are hesitant since the barrier is high for attempting entry on one's own. However, some businesses are taking on the challenge by gaining know-how through provision of gifts. The ratio for the top regions was significantly higher than that for the randomly selected regions. Presumably, the more gift orders a business receives, the more know-how and capacity they can accumulate for starting online sales.

Also, a common issue of rural businesses is their low profitability due to their wholesale business style. Once such businesses establish their own brand or secure their own customers, they would be able to lower the weight of low-margin wholesale and aim for higher corporate profitability. However, such cases were the minority in our research. Changes in form of sales (e.g., entry into retail from wholesale, or into restaurant business from retail) were only seen in $8.3 \%$ of the businesses in the top regions and $6.7 \%$ in the randomly selected regions.

As for whether businesses achieved sixth industrialization, which we asked agricultural and fishery businesses, $32.5 \%$ of the businesses in the top regions and $23.9 \%$ in the randomly selected regions replied that they did. This includes cases where farmers and fishery businesses built their own processing facilities to manufacture and sell processed goods, or where farmers started manufacturing and selling juice. A common issue in sixth industrialization is that businesses tend to be product-oriented and not market-oriented; however, one can immediately identify what kinds of products are popular on Hometown Tax Donation gift web portals. Also, since the gift market covers sales, the hurdle for managing sales is lower than that in a normal sixth industrialization. In this way, the gift market also drives engagement in sixth industrialization.

\subsubsection{Impact on Regional Investment and Lending}

Forward-looking investments are essential in raising corporate value. Yet, making investments is difficult for companies with uncertain business outlooks, whereby, corporate values and regional economies continue to shift toward contractual equilibrium. Nonetheless, if companies foresee business opportunities in the Hometown Tax Donation gift market, they may be motivated to make investments, and businesses that earn higher profits through provision of gifts would ideally invest surplus capital in future growth and strive to gain competitiveness in areas other than the gift 
market. In our survey, we asked for details and the amount of investments made to businesses who replied that they made capital investments. Results revealed that the total amount of capital investment made by all 45 businesses in 25 regions was some 150 million yen. Approximately two out of three of those investments did not use subsidies, but instead were self-financed. Investments ranged from purchase of large refrigerators and freezers to purchase of various processing equipment, construction of new shops, expansion of offices, and purchase of office automation equipment.

Meanwhile, the number of businesses that received new or additional loans from financial institutions to finance provision of gifts was not large, as shown in Fig. 4.11. Compared to the various changes and capital investments implemented by businesses mentioned above, the extent of lending and involvement by financial institutions seemed to be somewhat weak. Going forward, further involvement by regional financial institutions will be critical for the system to function more effectively as an SME policy. It is worth noting that among the businesses that received new or additional loans, $77.3 \%$ responded that they also made capital investments, indicating a high correlation between capital investment and loans.

\subsubsection{Effects from Matching Interests Between Municipalities and Businesses}

One of the three structural characteristics of Hometown Tax Donation is that municipalities actively support local businesses, and the extent of such support influences management capabilities of businesses and the amount of donation a municipality receives. Figure 4.13 shows results of a question to businesses regarding the discussions they had with municipalities.

\begin{tabular}{|c|c|c|c|c|}
\hline & \multicolumn{2}{|c|}{ Top regions } & \multicolumn{2}{|c|}{$\begin{array}{c}\text { Randomly } \\
\text { selected } \\
\text { regions }\end{array}$} \\
\hline & No. & $\%$ & No. & $\%$ \\
\hline Verifying contents and no. of orders & 84 & $36.8 \%$ & 59 & $27.8 \%$ \\
\hline New product development & 46 & $20.2 \%$ & 51 & $24.1 \%$ \\
\hline Product upgrades & 39 & $17.1 \%$ & 44 & $20.8 \%$ \\
\hline Checking inventory & 34 & $14.9 \%$ & 21 & $9.9 \%$ \\
\hline Securing personnel & 2 & $0.9 \%$ & 1 & $0.5 \%$ \\
\hline Obtaining subsidy & 3 & $1.3 \%$ & 2 & $0.9 \%$ \\
\hline Future capital investment & 2 & $0.9 \%$ & 1 & $0.5 \%$ \\
\hline Other & 18 & $7.9 \%$ & 33 & $15.6 \%$ \\
\hline Total & 228 & $100.0 \%$ & 212 & $100.0 \%$ \\
\hline No. of multiple answers & 65 & & 65 & \\
\hline
\end{tabular}

Fig. 4.13 Matters discussed with municipality officials 
Results show that while the most frequently discussed matter was verification of orders, the proportion for new product development and product upgrades was also high, implying that municipalities are offering detailed advice and serving a supportive role to businesses with an aim to capture more donations. Although not shown in the table, we also asked businesses whether they were satisfied with the support from municipalities, and some $90 \%$ in both the top and randomly selected regions responded in the affirmative. This suggests that support from municipalities is playing a certain role in the growth of local businesses. Conventional SME policies implemented by the national government or municipalities merely presented a list of initiatives, and businesses, who lack the necessary resource, had to do all the work, making it difficult to yield results. However, in the case of Hometown Tax Donation, municipal officials extensively support local businesses since success or failure in engagement directly affects the amount of donations a municipality receives. This aspect makes Hometown Tax Donation unique, and provides implications for regional SME Policies.

We also asked businesses whether they collaborated with other gift providers through sharing knowledge or know-how, and about half responded that they have or are interested in doing so, suggesting that Hometown Tax Donation may be prompting closer collaboration among local businesses. As long as all local businesses operate within the local market, they will need to compete against each other to win local customers; however, if businesses aim to win non-local customers, they can become partners who help each other advance. In fact, there have been cases where new products were developed through collaboration among local businesses, including in Fukaya City in Saitama Prefecture, Osaki City in Kagoshima Prefecture, and Okuizumo Town in Shimane Prefecture. Advances in such collaboration among local businesses should spur regional innovation and entrepreneurship.

\subsection{Implications for and Challenges of Initiating Regional Entrepreneurship Based on Survey Research}

The analysis results thus far unveiled that provision of gifts has prompted some local businesses to implement progressive business strategies, including entry into the secondary industry, or a move toward sixth industrialization. Furthermore, some businesses have expanded their sales channels beyond the gift market, and such movements should be reinforced going forward. Yet, although these developments require lending by regional financial institutions and active investments by businesses, such circumstances could not be verified.

The discussions above provide two insights into effective rural venture business and SME policies. One is the presence of a market with adequate competition. If there is a platform that serves as a dojo, local SMEs can prepare and train to enter full-scale markets (e.g., the e-commerce market). Importantly, in this dojo, general consumers should be the trainers providing guidance. This circumstance will urge 
local businesses to take a market-oriented approach and strive to provide products that will be selected by consumers. This scheme is different from the conventional scheme where businesses simply improved their paperwork skills in order to successfully obtain subsidies. The second is matching interests among municipalities and local businesses, and the promotion of intra-regional collaboration among local businesses.

Meanwhile, there is an issue that needs to be addressed; namely, establishing an exit strategy for the dojo. The value of Hometown Tax Donation will not be fully exercised if it merely creates irregular government-driven demand for gifts, and turns out to be nothing more than tax-driven support for rural SMEs' revenues. The system will only hold value if it guides businesses to "graduate" from the dojo and thereafter strive competently in regular markets. For example, Vegiko Vegiko based in Miyazaki Prefecture used to provide vegetables for smoothies as gifts, but later exited the gift market, and is currently achieving ample revenues by expanding its regular business through delivery service of fresh produce. More businesses need to become centered on regular e-commerce, as is the case of the confectionery cafe Cotoyu introduced in the previous chapter. In this way, businesses are required to effectively use the gift market, rather than depending on it, to boost brand recognition or conduct test marketing, and thereby achieve growth.

There is also a potential pitfall in matching interests between municipalities and businesses. Once businesses exit the gift market, as in the case of Vegiko Vegiko, donations to municipalities will decline. Since donations received by a municipality are directly linked to provision of gifts, it is necessary for municipalities to have businesses continue providing attractive gifts. This is the exact opposite of having businesses avoid depending on the gift market as discussed above, and striking a balance will be difficult.

Ideally, businesses should increase their revenues in both gift and regular markets; however, they then face the question of whether general consumers would pay the full price to buy products that were offered for almost no cost in the gift market. An optimal solution to this problem would be to create a local ecosystem where new local businesses constantly emerge, enter into the dojo market, and then graduate. To achieve this, it is important that businesses, municipalities and financial institutions make a concerted effort to generate regional entrepreneurship.

While such challenges remain to be addressed in terms of exit strategy, our research revealed that the Hometown Tax Donation gift market serves a certain role in fostering local businesses. Moving forward, the biggest challenge is to increase the ratio of businesses whose management capability indices improve through gift revenue, and to produce as many businesses as possible that can also strive in general markets. Furthermore, it is important that municipalities themselves not rely on gifts to receive donations, but instead make such efforts as winning the empathy of donors through presenting effective usage of donations. 


\section{References}

Hoda T, Kubo Y (2019a) Attribution analysis of gift providers of Hometown Tax Donation (In Japanese). Venture Rev 33:57-62

Hoda T, Kubo Y (2019b) Regional entrepreneurship of Hometown Tax Donation-a unique regional development tool: implications from new product developments and improvement in management capability indices by gift providers. Ann Jpn Assoc Regional Policy Sci 23:90-99

Open Access This chapter is licensed under the terms of the Creative Commons AttributionNonCommercial-NoDerivatives 4.0 International License (http://creativecommons.org/licenses/bync-nd/4.0/), which permits any noncommercial use, sharing, distribution and reproduction in any medium or format, as long as you give appropriate credit to the original author(s) and the source, provide a link to the Creative Commons license and indicate if you modified the licensed material. You do not have permission under this license to share adapted material derived from this chapter or parts of it.

The images or other third party material in this chapter are included in the chapter's Creative Commons license, unless indicated otherwise in a credit line to the material. If material is not included in the chapter's Creative Commons license and your intended use is not permitted by statutory regulation or exceeds the permitted use, you will need to obtain permission directly from the copyright holder.

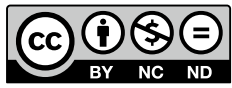

